\title{
Population modelling of Varroa jacobsoni Oud.
}

\author{
Johan N.M. Calis ${ }^{\text {a* }}$, Ingemar Fries ${ }^{\mathrm{b}}$, Stephen C. Ryrie \\ ${ }^{a}$ Department of Entomology, Wageningen Agricultural University, \\ POB 8031, 6700 EH Wageningen, the Netherlands \\ ${ }^{b}$ Swedish University of Agricultural Sciences, Bee Division, \\ Box 7044, S-570 07 Uppsala, Sweden \\ ' Department of Mathematical Sciences, University of the West of England, \\ Frenchay, Bristol BS16 IQY, UK
}

(Received 20 August 1998; accepted 22 February 1999)

\begin{abstract}
To understand population dynamics of the mite Varroa jacobsoni and to enable computer simulations, Fries et al. [12] incorporated available knowledge into a mite population model. In this paper, we update and extend this model by incorporating more recent data, in particular on mite invasion from bees into brood cells. By predicting invasion into and emergence from brood cells, the model proves to be useful to evaluate the effects of changes in model parameters on the mite population when the distribution of mites over bees and brood are important. The model predicts that a longer brood rearing period dramatically increases the mite population size and that a relatively larger number of drone brood cells leads to an increased population growth. As mite control treatments often only affect mites either in brood cells or on adult bees, the model can be used to evaluate their effectiveness and timing. The model indicates that changes in parameters that affect the reproductive success of the mites in brood cells have a large impact on the mite population. (1) Inra/DIB/AGIB/Elsevier, Paris
\end{abstract}

Apis mellifera / Varroa jacobsoni / population dynamics / model

\section{INTRODUCTION}

The parasitic mite of honey bees, Varroa jacobsoni (Acari: Varroidae), is a major obstacle to beekeeping throughout most temperate and some tropical regions of the world. Adult female mites feed on bees, and as honey bee brood becomes available, the mites leave the adult bees to reproduce inside the bee brood cells. Reproductive success inside the brood cells depends on various factors (reviewed by Donzé et al. [10]). As the bee emerges from the brood cells, the mite mother and her adult female

\footnotetext{
* Correspondence and reprints

E-mail: Johan.Calis@users.ento.wau.nl
} 
progeny return to the adult bees. If total mite mortality on the adult bees and in the brood is smaller than the production of new mites in the brood, the mite population will increase over time. The life cycle of mites in a honey bee colony is schematically represented in figure 1.

To help understand population dynamics of $V$. jacobsoni in colonies of European honey bees, models of different aspects of mite population dynamics have been presented $[2,3,9,13,15,27,30]$. A review of factors affecting mite population dynamics was presented by Fries et al. [12] together with differential equations modelling the mite population dynamics.

The model described here is an extended version of that by Fries et al. [12]. In the original model, the per capita number of reproductive cycles was set at 1.4. Second, invasion of mites into brood cells.was determined by a mean length of the phoretic period. In nature, the number of times a mother mite will reproduce is determined by the invasion rate into brood cells and the mortality rate of the mites. In the new version of the model, we included the equations on cell invasion rates presented by Boot et al. [3] and mite mortality data connected with the emerging infested bee [4], thereby avoiding the non-biological restrictions in the old model.

The invasion rate into brood cells can be calculated when colony size and numbers of brood cells are known. To simulate colony size and numbers of brood cells, we designed

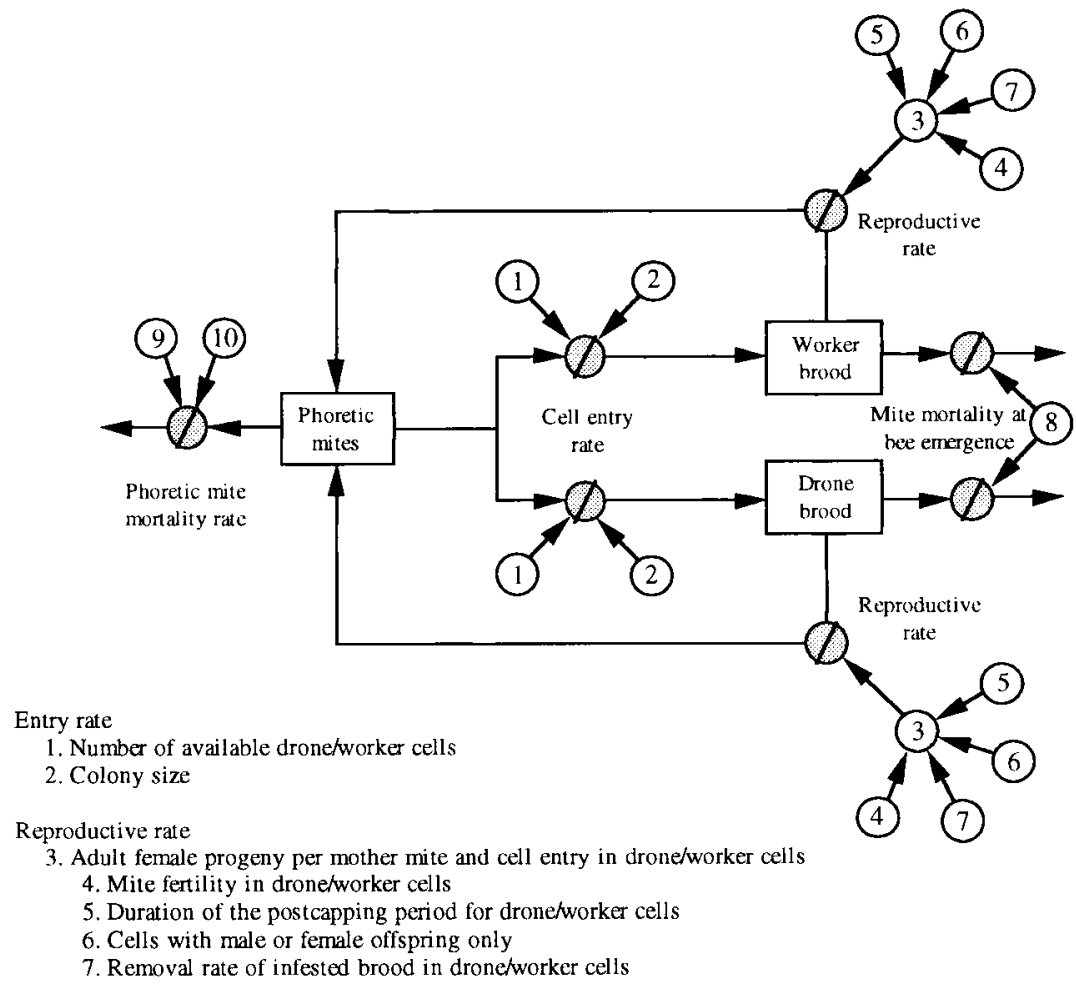

Mortality rates

8. Mite mortality at emergence from drone/worker cells

9. Phoretic mite mortality in summer

10. Phoretic mite mortality in winter

Figure 1. Diagram of V. jacobsoni mite population growth within a honey bee colony. 
a bee colony population model. Thus, the new model is comprised of two parts, a model of the bee colony, and a model of the mite population, which describe the populations they represent over a period of several years. The colony model follows a bee colony throughout the year from broodless hibernating conditions, via a period of breeding and growth in summer, and a period of decline in fall, returning to a broodless hibernating colony. Its output pattern does not change from year to year, and is unaffected by the mite model. The output pattern of the mite model does vary from year to year and is influenced by the colony model, and in particular by the number of bees and the number of brood cells present in the hive at any time.

The aim of this paper is to describe and explore the extended simulation model of the interaction between honey bees and mite populations. Such a model is used for exploring the effects of changes in various characteristics that relate to mite resistance, effects of beekeeping techniques, and to predict the effect of different control treatments.

\section{MATERIALS AND METHODS}

\subsection{The colony model}

The colony model describes the number of drone and worker brood cells in the colony on each day of the year. The basic colony model, like that of Fries et al. [12], is based on field data from Scotland on counts of numbers of drone and worker brood cells in colonies during the brood-rearing season as reported by Allen [1]. In addition, we use sets of brood data from midEuropean conditions (P. Rosenkranz, unpublished data) and from neo-tropical conditions [11]. The use of brood data from different climatic regions provides us with an opportunity to simulate $V$. jacobsoni population dynamics in different climatic zones. For the additional two brood data sets, we have assumed that the number of drone cells is a constant proportion of the number of worker cells ( $4 \%$; derived mean from the work of Allen [1]), because more precise data are lacking.

In the colony model, the amount of brood and the development time of the brood are used to calculate the number of emerging adult bees. The total number of adult bees is calculated by assigning a specified longevity of the bees during periods of brood rearing. During winter the death rate is chosen so that the colony returns to the same size as 1 year previously (for parameter values see table I). The brood data used and the number of bees simulated are illustrated in figure $2 a-c$.

\subsection{The mite population model}

Several processes contribute to changes in the population level of mites within the colony. Mites are either phoretic on the bees or are in the brood cells where they reproduce. This distribution depends on the invasion rate of phoretic mites into the brood. Both phoretic mites and mites in the brood are subjected to certain levels of mortality. The mite population dynamics is determined by invasion of mites into brood cells, reproductive factors and mortality factors.

\subsubsection{Invasion of mites into brood cells and mite emergence}

Boot et al. [3] measured the rate of invasion of mites into worker and drone cells in the field, and derived empirical relationships between the invasion rate per day $\left(r_{D}\right.$ and $r_{w}$ for drone and worker brood, respectively) and the ratio of the number of available cells to the number of adult bees: $r_{D}=-6.49 \mathrm{D} / \mathrm{B}$ and $r_{W}=-0.56 \mathrm{~W} / \mathrm{B}$, where $\mathrm{D}$ and $\mathrm{W}$ are the number of available drone and worker brood cells, respectively, and B is the weight in grams of adult bees in the colony. $\mathrm{D}$ and $\mathrm{W}$ are the number of brood cells that are capped over 1 day and are calculated from the total number of cells of both brood type and the specific development time; $B$, the weight of the bees, is calculated by assuming that one bee weighs $0.125 \mathrm{~g}$ (J. Calis, unpublished data)

Thus, depending on the weight of the colony, a specific number of brood cells that are being sealed over 1 day are invaded by:

$$
I=P\left\{1-\exp \left(-\left(r_{D}+r_{W}\right)\right)\right\}
$$

where $P$ is the number of phoretic mites and $I$ is the number of mites invading cells on that day. Invading mites divide themselves over worker and drone brood in proportion to the quantities $r_{w} /\left(r_{D}+r_{W}\right)$ and $r_{D} /\left(r_{D}+r_{w}\right)$, respectively. We have used these formulae in our model, with values of W, D and B varying with time as determined by the colony model being used. 
Table I. Standard parameter values used for simulation of $V$. jacobsoni populations.

\begin{tabular}{|c|c|c|c|}
\hline Parameter & \multicolumn{2}{|l|}{ Value } & Comments \\
\hline Initial population (phoretic mites) & \multicolumn{2}{|l|}{10} & \\
\hline Simulation starting day & \multicolumn{2}{|l|}{ 1 January } & \\
\hline Brood production & \multirow{3}{*}{\multicolumn{2}{|c|}{$\begin{array}{l}\text { northern } \\
\text { neo-tropical } \\
\text { central European }\end{array}$}} & Allen [1] \\
\hline & & & Echazaretta and Paxton [11] \\
\hline & & & Rosenkranz (unpublished) \\
\hline Drone brood development period & \multicolumn{2}{|c|}{24 days } & \\
\hline Worker brood development period & \multicolumn{2}{|l|}{21 days } & \\
\hline Drone brood postcapping period & \multicolumn{2}{|l|}{14 days } & \\
\hline Worker brood postcapping period & \multicolumn{2}{|l|}{12 days } & \\
\hline Summer bee lifespan & \multicolumn{2}{|l|}{31 days } & Taranov and Azimov [31] \\
\hline Winter bee mortality & \multicolumn{2}{|l|}{ variable } & see text \\
\hline Mite invasion rate & \multicolumn{2}{|l|}{ variable } & Boot et al. [3] \\
\hline Mite infertility on drone brood & $5 \%$ & $\left(=\mathrm{j}_{\mathrm{D}}\right)$ & see Fries et al. [12] \\
\hline Mite infertility on worker brood & $15 \%$ & $\left(=\mathrm{j}_{\mathrm{W}}\right)$ & see Fries et al. [12] \\
\hline $\begin{array}{l}\text { Mean number of female offspring in a } \\
\text { worker cell with female offspring }\end{array}$ & 1.45 & $\left(=f_{w}\right)$ & see Fries et al. [12], Martin [23] \\
\hline \multicolumn{4}{|l|}{ Mean number of female offspring in a } \\
\hline Emergent mite mortality & $22 \%$ & $(=1-s)$ & Boot et al. [4] \\
\hline Uncapping of infested cells & $5 \%$ & $(=\mathrm{u})$ & $\begin{array}{l}\text { see Fries et al. [12], Calis } \\
\text { (unpublished) }\end{array}$ \\
\hline $\begin{array}{l}\text { Proportion of worker cells with } \\
\text { only male offspring }\end{array}$ & $9 \%$ & $\left(=m_{W}\right)$ & Donzé [10] \\
\hline \multicolumn{4}{|l|}{ Proportion of drone cells with } \\
\hline \multicolumn{4}{|l|}{ Proportion of female mites dying in } \\
\hline \multicolumn{4}{|l|}{ Proportion of female mites dying in } \\
\hline drone cells before reproduction & $8 \%$ & $\left(=g_{D}\right)$ & Martin [24] \\
\hline Summer mite mortality & \multicolumn{2}{|l|}{ variable } & Boot et al. [4], Kraus [19] \\
\hline Winter mite mortality & 0.004 & & see Fries et al. [12] \\
\hline Postcapping influence factor & 1.0 & $\left(=p_{w}, p_{p}\right)$ & see text \\
\hline
\end{tabular}

The rate of invasion of mites into brood cells thus arises from a dynamic relationship between the number of available brood cells and the number of bees on which the mites are distributed. The invasion rate equations have proved useful in describing the efficacy of trapping mites in worker brood [7] or in drone brood [8]. Martin [25] recently also made an attempt to integrate knowledge on brood cell invasion into a population model. However, he interpreted the work of Boot et al. [3] quite differently. Since Martin let the same phoretic mites invade worker and drone brood independently, mites have to be divided artificially between worker and drone brood cells in his model. In our model, the division between worker and drone brood follows directly from the invasion rate equations above.
The number of mites that emerge daily from cells is derived from the number that invaded these brood cells one postcapping period earlier (using a delay function), modified to reflect mite reproduction and mortality in the cells.

\subsubsection{Reproduction}

Once the mites have entered brood cells and the cells have been sealed, the mother mite may start reproduction. Some mites die before they are able to start reproduction, partly because they become trapped between the cell wall and the bee cocoon. Other mites may fail to start reproduction, and of those that do reproduce some may produce non-viable offspring. In addition 

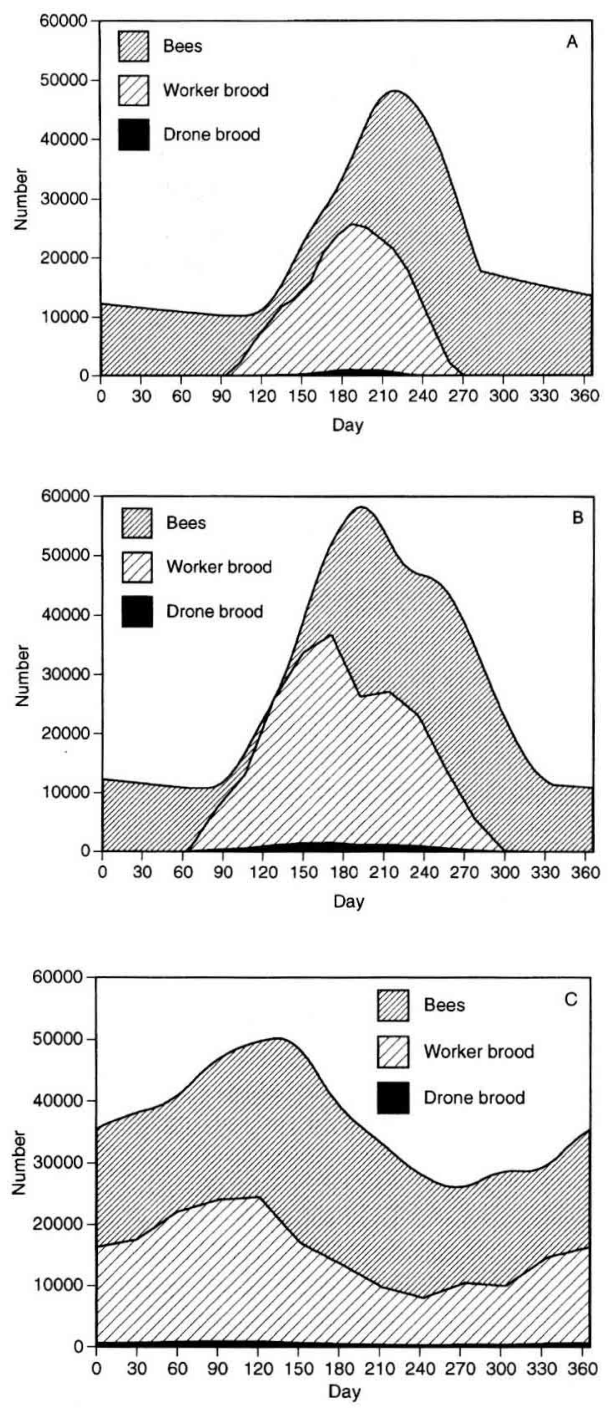

Figure 2. A) Northern European colony model. B) Central European colony model. C) Tropical colony model.

to female juvenile mortality, some mites produce only male progeny. Reproduction may be interrupted as bees uncap sealed cells and remove parasitised bee pupae. The reproductive success of the mite is also influenced by the duration of the postcapping period where a prolonged period increases the average number of viable female offspring. K. Langenbach (unpublished data) found that a reduction in the postcapping period of worker brood from 12 days to 11 days resulted in a $50 \%$ reduction in the number of offspring. Büchler and Drescher [5] found that a 1-h reduction of the postcapping period in worker brood reduced the mite population growth by $8.7 \%$. We have linearly interpolated these findings to postcapping periods between 11 and 13 days, thus, ranging from a $50 \%$ reduction to a $150 \%$ increase, respectively. For drone brood we assumed a similar reduction and increase between 12 and 16 days.

We have considered new data on male mite mortality in sealed brood cells [10, 23, 24]. The fact that a surprisingly large number of infested cells lack male progeny does have implications for population dynamics. Young mites that have not mated may either parthenogenetically produce only sons or may fail to produce offspring at all. In our model, we consider these mites and regard unmated mites as a part of the mite population.

\subsubsection{Mite mortality}

The natural mortality rate of phoretic mites in summer is taken to be the sum of mites lost after falling from bees in the hive, and mites lost via foragers that do not return to the colony. The rate at which mites fall from bees is taken to be $0.6 \% /$ day, following the findings of Boot et al. [4]. Further, we assume that bees that die during the summer are foragers that fail to return to the hive and that mites on these bees are lost from the mite population. The daily number of mites lost on non-returning foragers is calculated assuming that the rate of infestation of the foragers is one third of the average infestation of bees [19], their number being calculated by the colony model and with the lifespan of adult bees as shown in table $I$. The winter mortality rate is assumed to be $0.4 \%$ per day, as in Fries et al. [12].

Boot et al. [4] found that $22 \%$ of emerging mites, mothers and female offspring, fall off the host bees to the bottom of the colony in the first 3 days following emergence, which we have included in our model.

Summarising, mites on bees are subjected to mortality and losses in the field. When they invade brood cells, they may reproduce and increase their numbers. If we define reproductive success as the number of living female mites, including the mother, which emerge from a brood 
cell per invading mite, then for worker brood this is:

$$
R_{W}=\left\{f_{w} p_{w}\left(1-u-j_{w}-g_{w}-m_{w}\right)+1\right\} s
$$

where $R_{W}$ is the reproductive success per invading mite in worker brood; $f_{w}$ is the number of daughters per mite in worker brood; $p_{w}$ is a factor representing influence of postcapping period on the number of offspring in worker brood; $\mathbf{u}$ is the fraction of cells uncapped by bees; $j_{w}$ is the fraction of infertile female mites in worker cells; $g_{W}$ is the fraction of female mites in worker cells which die before reproducing; $m_{W}$ is the fraction of female mites that produce only male offspring; $s$ is the fraction of emerging mites which survive emergence. brood.

A similar set of relationships holds for drone

The values of $R_{W}$ and $R_{1}$ derived from the parameter values in table $I$ are 1.56 and 2.32 live emerging mites per invaded mite, respectively.

\section{RESULTS AND DISCUSSION}

\subsection{Mite population growth}

The model calculates the number of adult female mites present on adult bees and in brood cells. The following simulations demonstrate how the mite population will change over time using three different sets of brood data in colonies that do not swarm and are not subject to mite control.

In figure 3 , the mite population growth using brood data of northern, central Euro- pean and neo-tropical origin is presented graphically. The simulations start on 1 January with an initial population of ten phoretic mites and continue for four successive years. The model does not include the negative impact that high mite levels may impose on bee colonies and thus the model allows the mite population to increase beyond levels tolerated by bee colonies. This is an important limitation of the model, because interaction between the mite population and the colony is evident at high mite population levels.

The duration of the brood-rearing period has a dramatic impact on the mite population. Under neo-tropical brood-rearing conditions, colonies are likely to succumb to infestation within a year if the mite population is left uncontrolled. This is in agreement with available data from southern Europe and California, where mite growth rates may cause colony death within a year after effective mite control measures [16, 21 ]. Under northern brood-rearing conditions, where mite mortality during broodless winter conditions causes a decrease in the mite population, the model predicts relatively low mite population levels for the first 2 years of the infestation. In the third year, the mite population may reach damaging levels and by the fourth year the infestations are likely to cause colony death. This pattern of development is supported by field data from Finland [18]. Central European

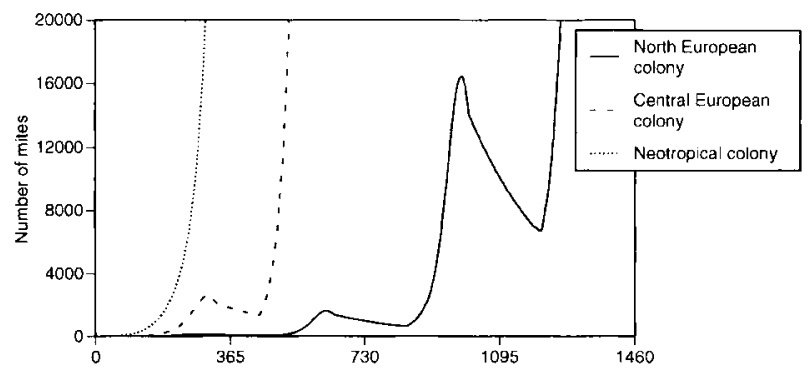

Figure 3. Mite population growth in relation to honey bee colony development. 
brood data give rise to mite population growth that is intermediate to northern and neo-tropical growth. Under these conditions, bee colonies are likely to be severely damaged by the mite infestation within 2 years of the initial infestation. The presented sets of brood data, besides those from Scotland [1], do not contain actual numbers of drone cells, since they were not known. We used as numbers of drone brood cells $4 \%$ of the number of worker brood cells; a mean of the data from Scotland. This extrapolation may be unrealistic, but the simulations still illustrate the importance of extended periods of brood rearing. To make realistic simulations for different brood-rearing patterns, however, data on numbers of brood cells of both drone and worker brood cells throughout the year are needed.

Mite populations build up relatively fast during the summer months. Observations of mite population increase have been made by Calatayud and Verdu [6] using $A . m$. iberica. They found that the mite population growth is exponential, i.e. that the population is proportional to $\exp (\mathrm{rt})$, where the value of the growth parameter $r$ is approximately 0.021 per day. This implies that the population would double in size in a period of 33 days. The results of our model are in accordance with this: a logarithmic plot of mite population versus time shows that population growth during the peak of brood rearing is indeed exponential, irrespective of what brood data are being used. We find the value of $r$ to be 0.023 per day, somewhat greater than that found by Calatayud and Verdu, and corresponding to a population doubling time of 30 days. In all further runs of our model, we have only used the northern European brood data for simplicity.

\subsection{Cell passages, distribution over bees and brood, mortality rate}

Another way to test model predictions is to compare the number of cell passages made by an individual mite. A probabilistic model of mite behaviour can be used to calculate the number of cell passages made by a single mite. Suppose that, on a given day, a mite may be either on a bee or in a cell, and that the daily probabilities of transition between these states are:

$b=\operatorname{Pr}($ mite on bee on day i I mite on bee on day $\mathrm{i}-1)$

$c=\operatorname{Pr}($ mite in cell on day $\mathrm{i} I$ mite on bee on day $\mathrm{i}-1)$

$\mathrm{d}=\operatorname{Pr}($ mite dies on day $\mathrm{i} I$ mite on bee on day i)

$\mathrm{e}=\operatorname{Pr}($ mite dies during cell passage $I$ mite already in cell)

then the probability distribution of $\mathrm{N}$, the number of cell passages made by an individual mite, is given by:

$$
\begin{gathered}
\operatorname{Pr}(N=n)=\{c(1-e) /(1-b)\}^{n}\{d /(1-b) \\
+e /(1-e)\}(\text { for } n>0)
\end{gathered}
$$

and

$$
\operatorname{Pr}(\mathrm{N}=0)=\mathrm{d} /(1-\mathrm{b})
$$

Further analysis shows that the mean $<\mathrm{N}>$ of this distribution is

$$
<\mathrm{N}>=\mathrm{c} /(\mathrm{d}+\mathrm{ce}) .
$$

In our model we have an emergent mite mortality, e, of $22 \%$. The death rate during the phoretic phase, $\mathrm{d}$, is 0.006 per day as in our model. Values of $b$ and $c$ are calculated by the model on each day of a simulation as being the proportion of mites which remain on bees and enter a cell, respectively, as shown in figure 4 . The mean number of cell passages per mite (figure 4), during the brood-rearing period, is fairly constant at about 4, an estimate that contrasts with the findings of Fries and Rosenkranz [13]. They made observations on the number of cell passages and suggest that this figure lies between 1.5 and 2.0 per mite. They observed an average loss of about $50 \%$ of the mites per cell passage, from which we can calculate the number of cell passages to be 1.8 . However, in their experiment the loss of mites during the first cell passage was much higher than in the subsequent cell passages. 


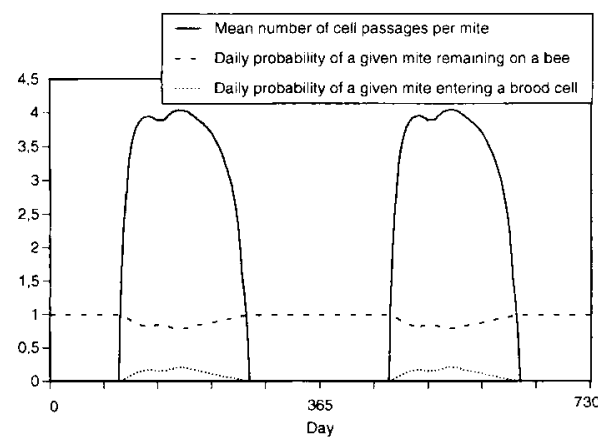

Figure 4. Number of cell passages for a single mite.

If we disregard this initial loss of mites, as it may have been due to the experimental procedure of introducing the mites into the colonies, the number of cell passages may well be as high as we have now calculated.

The model also predicts the distribution of mites over adult bees and brood. As soon as brood rearing starts the mites start invading brood cells and a distribution pattern is generated as shown in figure 5, which is in agreement with empirically determined distributions [14]. Figure 5 also shows the daily rate of mite mortality inside the bee colony, including mortality of phoretic mites inside the colony and mortality upon emergence. The mortality rate inside the colony is especially relevant because it is virtually the only feature of the mite's population dynamics which is easily observable. Daily mortality is, for almost the entire brood-rearing period, between 1 and $2 \%$ of the mite population.

\subsection{Sensitivity analysis}

Variation of one parameter at a time will help to assess influence of that parameter on the model predictions. Parameters that have the largest impact on mite population growth are those relevant for manipulation by the beekeeper or for obtaining mite-resistant bees through selection. In figure 6 we show the effect on the peak mite population in year 3 by altering: 1 ) the mean number of female offspring in a cell with female offspring in worker and drone cells (the effective reproductive success of the mite becomes less because of factors such as male mortality and infertility); 2) the quantity of drone and worker brood cells present in the colony; and 3) phoretic mite mortality during the summer. The values used are shown in table II.

Reproductive success has a large impact on population growth, and honey bee traits that influence the reproductive success may be relevant for selection of mite-resistant bees. Also, increased phoretic mortality, e.g. due to grooming behaviour of the bees, has a large impact on population growth. The quantity of drone brood present in the colony, relatively easily manipulated by the beekeeper, also has a strong effect on population growth. Decreasing the amount of worker brood, which gives the same results as decreasing the attractiveness of the worker brood, has the counterintuitive effect of increasing somewhat mite population levels owing to the higher proportion of mites which invade drone brood.

\subsection{Responses to treatment regimes}

The following three types of $V$. jacobsoni control methods are used.

1) Biotechnical methods, such as drone culling and queen trapping; these methods are generally labour-intensive, but carry no risk of contamination of stores and may be used during the summer period.

2) Methods based on (environmentally safe) organic acids, such as oxalic, lactic or formic acids, or on essential oils; again these can be time-consuming to use, but can be effective.

3) Methods based on synthetic acaricides such as Bayvarol (e.g. flumethrin) or Apis$\tan$ (e.g. fluvalinate), which are often highly effective, but contaminate bee products and eventually reduce acaricide susceptibility 


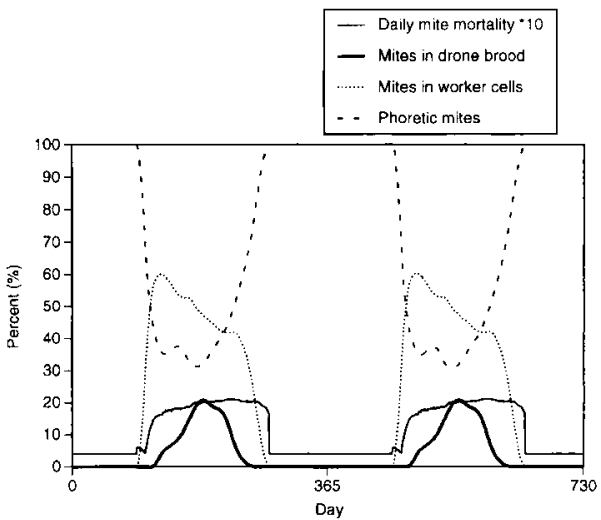

Figure 5. Distribution of mites over worker and drone brood and bees and daily mite mortality using the northern European colony model.

of the mites through continued use. Synthetic acaricides should only be applied at the end of the season.

Here, we have modelled the effect of using drone culling in a systematic way, and of using an acid treatment in both summer and winter.

\subsubsection{Drone culling}

This control method involves the introduction of drone combs and their removal after sealing during the brood-rearing season. The preference of $V$. jacobsoni for drone rather than worker brood (see e.g. [3]) means that a large proportion of mites inside brood cells will be in drone cells, and

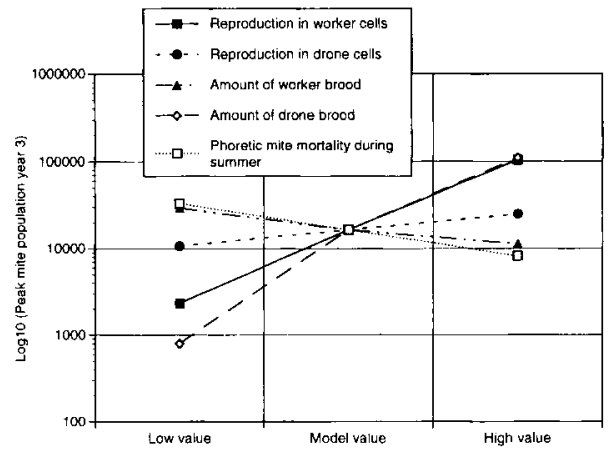

Figure 6. Sensitivity of peak mite populations in year 3 to changes in model parameters.

removal of relatively small amounts of drone brood cells therefore provides a way of destroying mites.

We have modelled drone brood removal by supposing that a drone comb is introduced into the brood nest, that the bees raise 1500 drone larvae in this comb, that the brood cells are invaded by phoretic mites as described and are capped evenly distributed over a 1-week period, and that the comb is removed after sealing together with the trapped mites. The model predicts a considerable effect on the mite population ( figure 7). A repeated insertion and removal of drone brood, once on 1 June and once on 1 July, reduces the peak mite population in year 3 from about 16000 to about 1750 if

Table II. Values used for sensitivity analysis.

\begin{tabular}{lccc}
\hline & Low & Medium & High \\
\hline $\begin{array}{c}\text { Mean number of female } \\
\text { offspring, worker cells }\end{array}$ & 1.25 & 1.45 & 1.75 \\
$\begin{array}{c}\text { Mean number of female } \\
\text { offspring, drone cells }\end{array}$ & 2.4 & 2.7 & 3.0 \\
Quantity of drone brood & 0 & $100 \%$ & $200 \%$ \\
Quantity of worker brood & $50 \%$ & $100 \%$ & 150 \\
Summer mite mortality & 0.003 & 0.006 & 0.009
\end{tabular}

The medium values are standard parameter values. 


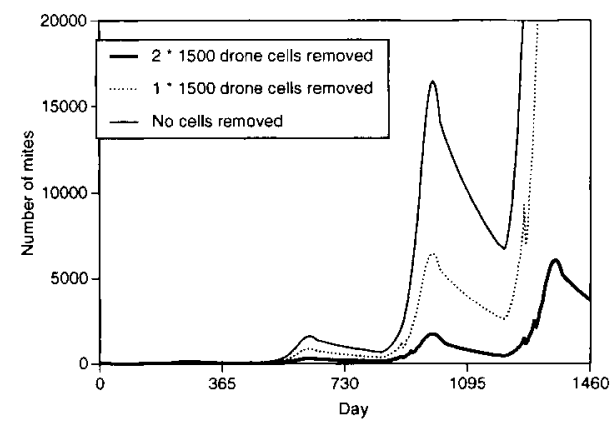

Figure 7. Effect of simulated drone brood removal.

there is no reinvasion. This is in agreement with field observations from removing drone brood [28].

\subsubsection{Acid treatments}

Lactic and oxalic acids have been found to kill over $80 \%$ of mites on adults (not in cells) at the time of treatment $[17,20]$. They are most useful when applied outside the brood-rearing period, in late autumn or winter, but are also useful at other times of the year as a 'knock-down' treatment.

We have modelled the effect of acid treatment by assuming that a predetermined proportion of mites present on bees are killed at the time of the application. We have compared the effects of a single treatment in autumn after the end of the brood-rearing period, with two treatments in summer. A single annual treatment on 27 October with a mortality rate of $90 \%$ results in a population level which is very low and stable provided that there is no reinvasion of mites (figure 8). Under central European brood conditions, this is not sufficient because of the longer breeding period of the mite (data not shown). However, a mortality rate of only $70 \%$ in this late treatment results in a population level which increases over a few years to levels which are likely to be fatal to the colony. The use of two treatments in summer is not an acceptable alternative: even with a mortality rate of $90 \%$, the mite build-up is considerable over several years (figure 8). With brood produced outside of the relatively short brood-rearing period normal for Scotland [1], the requirement of treatment efficacy will be even higher.

\subsection{Colony reinvasion}

The numbers of new mites reinvading the colony can be considerable [29]. In figure 9 we show how the mite population responds to a reinvasion of five mites per day during autumn, from 7 October to 16 November. As would be expected, the population increases faster than would be the case with no such reinvasion.

Despite reinvasion, a treatment with a mortality rate of $90 \%$ applied on 7 October (i.e. before the start of the invasion) reduces the population to a level at which the annual increase is sustainable using Scottish brood data [1].

\section{CONCLUSIONS}

In conclusion, since brood cell invasion is crucial in the life cycle of $V$. jacobsoni, the integration of knowledge on brood cell invasion into the population dynamics model of Fries [12] allows more realistic simulations

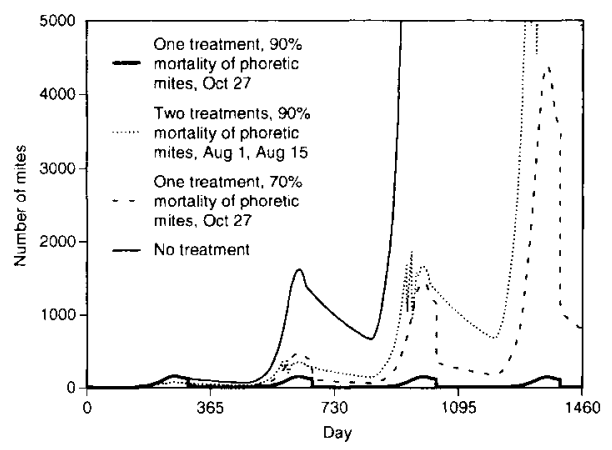

Figure 8. Effect of simulated acid treatments. 


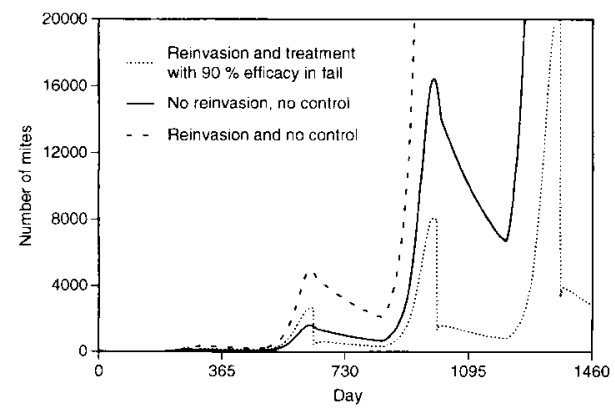

Figure 9. Effect of autumn invasion on mite populations.

of mite populations. The model can be used as a tool to evaluate control strategies, to evaluate the impact of honey bee traits that may lead to resistant bees, and to gain insight into the mite-bee relationship. It should be emphasised that for a realistic simulation of the $V$. jacobsoni population dynamics in a particular area using this model, it is vital to use brood data that is relevant to the situation for which predictions are to be made. The model is summarised in Appendix 1 and will be made available on disk for researchers and beekeepers using the 'Stella'-software package that runs on a personal computers.

\section{ACKNOWLEDGEMENTS}

SCR gratefully acknowledges financial assistance in the form of a travel grant from the C.B. Dennis British Beekeepers' Research Trust. We thank J. Beetsma, M. Beekman, W.J. Boot, J.C. van Lenteren and M.W. Sabelis for their valuable comments on drafts of the manuscript.

\section{Résumé - Modélisation des populations} de Varroa jacobsoni. L'acarien Varroa jacobsoni Oudemans (Mesostigmata, Varroidae) est un parasite majeur de l'abeille mellifère, Apis mellifera $\mathrm{L}$. Afin de mieux comprendre la dynamique des populations de $V$. jacobsoni et de permettre des simulations mathématiques, Fries et al. [12] ont intégré les connaissances actuelles dans un modèle de population qui permet à une population initiale d'acariens de varier quotidiennement sur n'importe quelle période. Dans cet article, nous décrivons un développement de ce modèle qui intégre des données plus récentes portant spécifiquement sur l'invasion des cellules de couvain par les acariens phorétiques. Le modèle populationnel de l'acarien est mis en relation avec un modèle de la colonie d'abeilles. Cela permet une évaluation des évênements plus réaliste lorsque la répartition des acariens sur les abeilles et le couvain est importante. Nous avons utilisé le modèle pour évaluer, entre autres : i) l'influence de diverses conditions climatiques sur la population d'acariens, ii) les caractéristiques comportementales des abeilles pouvant conduire à une résistance aux acariens, iii) le nombre relatif de cellules de couvain, et iv) diverses stratégies de lutte. Le modèle prédit à la fois le nombre d'acariens vivants et d'acariens morts tombant de la colonie tout au long de l'année et peut donc être utilisé pour suivre la population d'acariens afin d'optimiser les stratégies de lutte. Le modèle, qui fonctionne sur un ordinateur personnel, sera mis à disposition des scientifiques et des apiculteurs. (C) Inra/DIB/AGIB/Elsevier, Paris

\section{Apis mellifera / Varroa jacobsoni / dynamique des populations / modèle}

\section{Zusammenfassung - Ein Populations-} modell für Varroa jacobsoni. Die parasitische Milbe Varroa jacobsoni ist eine der wichtigsten Krankheiten der Honigbiene Apis mellifera L. Um ein besseres Verständnis der Populationsdynamik der Milben zu erreichen und um mathematische Simulationen zu ermöglichen, faßten Fries et al. [12] den Wissenstand jener Zeit in einem Populationsmodell zusammen. In diesem konnte die Entwicklung der Milbenpopulation über einen Zeitraum von mehreren Jahren dargestellt werden. In dem vorliegenden Artikel beschreiben wir eine Ausweitung dieses Modells, in die neuere Daten 
besonders über das Eindringverhalten phoretischer Milben in die Zellen einbezogen wurden. Das Modell der Milbenpopulation ist hierbei mit einem Modell des Bienenvolkes verbunden $(A b b, 3)$. Hierdurch wird eine realistischere Abschätzung des Einflusses von Ereignissen ermöglicht, die bei der Verteilung von Milben auf die Bienen und die Brut eine Rolle spielen. Das Modell sagt voraus, da $\beta$ die Milbenpopulation durch eine längerere Brutperiode dramatisch gesteigert wird $(A b b .2 a-c)$, und da $\beta$ eine verhältnismäßig hohe Anzahl an Brutzellen zu schnellerem Populationswachstum führt. Ebenso macht das Modell Aussagen zu der Anzahl lebender und toter Milben, die über das ganze Jahr hinweg aus dem Bienenvolk herunterfallen. Es kann daher genutzt werden, um die Milbenpopulationen zu überwachen. Dies kann hilfreich für die Optimierung von Bekämpfungsstrategien sein. Da die Bekämpfungsmaßnahmen zumeist entweder nur die Milben auf den Bienen oder nur die Milben in der Brut erfassen, kann das Modell nützlich zur Abschätzung ihrer Wirksamkeit (Abb. 7-8) oder der günstigsten Anwendungszeiten sein. Die Berechnungen weisen darauf hin, da $\beta$ Änderungen in den Parametern des Reproduktionserfolgs in den Brutzellen die Milbenpopulation sehr stark beeinflussen $(A b b .6)$. Das Modell soll Forschern und Bienenhaltern zugänglich gemacht werden und ist auf einem Personal Computer lauffähig. (C) Inra/DIB/AGIB/Elsevier, Paris

\section{Apis mellifera / Varroa jacobsoni / Populationsdynamik / Modell}

\section{REFERENCES}

[1] Allen M.D., The effect of a plentiful supply of drone comb on colonies of honeybees, J. Apic. Res. 4 (1965) 109-119.

[2] Boot W.J., Beetsma J., Calis J.N.M., Behaviour of Varroa mites invading honey bee brood cells, Exp. Appl. Acarol. 18 (1994) 371-379.

[3] Boot W.J., Schoenmaker J., Calis J.N.M. Beetsma J., Invasion of Varroa jacobsoni into drone brood cells of the honey bee, Apis mellifera, Apidologie 26 (1995) 109-118.
[4] Boot W.J., Calis J.N.M., Beetsma J., Does time spent on adult bees affect reproductive success of Varroa mites?, Entomol. Exp. Applic. 75 (1995) $1-7$.

[5] Büchler R., Drescher W., Variance and heritability of the capped developmental stage in European Apis mellifera L. and its correlation with increased Varroa jacobsoni infestation, J. Apic. Res. 29 (1990) 172-176.

[6] Calatayud F., Verdu M.J., Number of adult female mites Varroa jacobsoni Oud. on hive debris from honeybee colonies artificially infested to monitor mite population increase, Exp. Appl. Acarol. 19 (1995) 181-188.

[7] Calis J.N.M., Boot W.J., Beetsma J., Eijnde J.H.P.M. van den, Ruijter A. de, Steen J.J.M. van der, Control of Varroa mites by combining trapping in honey bee worker brood with formic acid treatment of the capped brood outside the colony: Putting knowledge on brood cell invasion into practice, J. Apic. Res. (1999) in press.

[8] Calis J.N.M., Beetsma J., Boot W.J., Eijnde J.H.P.M. van den, Ruijter A. de, Steen J.J.M. van der, Effective biotechnical control of Varroa jacobsoni mites: Applying knowledge of brood cell invasion to trap honey bee parasites in drone brood, J. Apic. Res. (1999) in press.

[9] Camazine S., Factors affecting the severity of Varroa jacobsoni infestations on European and Africanized honey bees, in: Needham G.R., Page R.E., Delfinado-Baker M., Bowman C.E (Eds.), Africanized Honeybees and Bee Mites, Ellis Horwood, Chichester, 1988, pp. 444-451.

[10] Donzé G., Hermann M., Bachofen B., Guerin P.M.. Effect of mating frequency and brood cell infestation rate on the reproductive success of the honeybee parasite Varroa jacobsoni, Ecol. Entomol. 21 (1996) 17-26.

[11] Echazaretta C.M., Paxton R.J., Comparative colony development of Africanized and European honey bees (Apis mellifera) in lowland neotropical Yucatan, Mexico, J. Apic. Res. 36 (1997) 89-103.

[12] Fries I., Camazine S., Sneyd J., Population dynamics of Varroa jacobsoni: a model and a review, Bee World 75 (1994) 5-28.

[13] Fries I., Rosenkranz P., Number of reproductive cycles of Varroa jacobsoni in honeybee (Apis mellifera) colonies, Exp. Appl. Acarol. 20 (1996) 103-112.

[14] Fuchs S., Untersuchungen zur Quantitativen Abschätzung des Befalls von Bienenvölkern mit Varroa jacobsoni Oudemans und zur Verteilung des Parasiten im Bienenvolk, Apidologie 16 (1985) 343-368.

[15] Fuchs S., Langenbach K., Multiple infestation of Apis mellifera $\mathbf{L}$. brood cells and reproduction in Varroa jacobsoni Oud., Apidologie 20 ( 1998 ) 257-266. 
[16] Garcia-Fernández P., Benítez Rodrigues R., Orantes-Bermejo F.J., Influence of climate on the evolution of the population dynamics of the Varroa mite on honeybees in the south of Spain, Apidologie 26 (1995) 371-380.

[17] Imdorf A., Charriere J.-D., Maquelin C., Kilchenmann V., Bachofen B., Alternative Varroa control, Am. Bee J. 136 (1996) 189-193.

[18] Korpela S., Aarhus A., Fries I., Hansen H., Varroa jacobsoni Oud. in cold climates: population growth, winter mortality and influence on the survival of honey bee, J. Apic. Res. 31 (1992) 157-164.

[19] Kraus B., Koeniger N., Fuchs S., Unterscheidung $z$ wischen Bienen verschiedenen alters durch Varroa jacobsoni Oud. und Bevorzugung von Ammenbienen im Sommervolk, Apidologie 17 (1986) 257-266.

[20] Kraus B., Berg S., Effect of a lactic acid treatment during winter in temperate climate upon Varroa jacobsoni Oud. and the Bee (Apis mellifera) Colony, Exp. Appl. Acarol. 18 (1994) $459-468$.

121| Kraus B., Page R.E. Jr, Population growth of Varroa jacobsoni Oud. in Mediterranean climates of California, Apidologie 26 (1995) 149-157.

[22] Kustermann, T., Populationsstruktur der Varroa-milbe, Deutsches Imker-Journal 1 (1990) $436-437$.

[23] Martin S.J., Ontogenesis of the mite Varroa jacobsoni Oud. in worker brood of the honeybee Apis mellifera $\mathrm{L}$. under natural conditions, Exp. Appl. Acarol. 18 (1994) 87-100.

\section{APPENDIX 1: Summary of Varroa jacobsoni model}

Consider female mites only, and let:

$P_{n}$ be the number of phoretic mites on day $n ; I_{n}$ be the number of phoretic mites which enter a brood cell on day $n ; E_{n}$ be the number of mites which emerge from cells with the adult bee on day $n$ (including the original mother mite); and $\mathrm{M}_{n}$ be the number of phoretic mites which die on day $n$.

Then the equation governing the $V$. jacobsoni model is

$$
P_{n}=P_{n^{-1}}+E_{n}-I_{n}-M_{n}
$$

[24] Martin S.J., Ontogenesis of the mite Varroa jacobsoni Oud. in drone brood of the honeybee Apis mellifera $\mathrm{L}$. under natural conditions, Exp. Appl. Acarol. 19 (1995) 199-2 10.

[25] Martin S.J., A population model for the ectoparasitic mite Varroa jacobsoni in honey bee (Apis mellifera) colonies, Ecol. Model. (1999) in press.

[26] Moosbeckhofer R., Fabsicz M., Kohlich A., Untersuchungen über die Abhängigkeit der Nachkommensrate von Varroa jacobsoni Oud. vom Befallsgrad der Bienenvölker, Apidologie 19 (1988) 181-208.

[27] Omholt S.W., Crailsheim K., The possible prediction of the degree of infestation of honeybee colonies (Apis mellifera) by Varroa jacobsoni Oud. by means of its natural death-rate: a dynamic model approach, Nor. J. Agric. Sci. 5 (1991) 393-400.

[28] Rosenkranz P., Engels W., Konsequente Dronenbrutentnahme, eine wirksame biotechnische Massnahme zur Minderung von Varroa-Schäden an Bienenvölkern, Allg. Dtsch. Imkerztg. 21 ( I985) 265-271.

[29] Sakofski F., Koeniger N., Fuchs S., Seasonality of honey bee colony invasion by Varroa jacobsoni Oud., Apidologie, 21 (1990) 547-550.

[30] Schulz A.E., Reproduktion und Populationsentwicklung der Parasitischen Milbe Varroa jacobsoni Oud. in Abhängigkeit vom Brutzylus ihres Wirtes Apis mellifera L., Apidologie 15 (1984) 401-420.

[31] Taranov G.F., Azimov T.N., The length of life of honey bees, Pchelovodsto 92 (1972) 16-17 (in Russian).

with

$$
\begin{gathered}
E_{n}=I_{w, n-N w} R_{w}+I_{d, n-N d} R_{d} \\
I_{n}=P_{n}\left\{1-\exp \left(-\left(r_{d, n}+r_{w, n}\right)\right)\right\} \\
M_{n}=k P_{n}
\end{gathered}
$$

where $I_{w, n}, I_{d, n}$ are the number of mites entering worker and drone brood cells, respectively, on day $n$, evaluated as:

$$
I_{w, n}=I_{n} r_{w, n} /\left(r_{w, n}+r_{d, n}\right)
$$

and

$$
I_{d, n}=I_{n} r_{d, n} /\left(r_{w, n}+r_{d, n}\right)
$$


$\mathrm{Nw}, \mathrm{Nd}$ are the postcapping periods for worker and drone brood, respectively; $r_{w, n}$ is the proportion of phoretic mites entering cells on day $\mathrm{n}$ which enter worker cells, evaluated thus:

$$
\mathrm{r}_{\mathrm{w}, \mathrm{n}}=-0.56 \mathrm{w}_{\mathrm{n}} / \mathrm{B}_{\mathrm{n}}
$$

$r_{d, n}$ is the proportion of phoretic mites entering cells on day $n$ which enter drone cells, evaluated thus:

$$
r_{d, n}=-6.49 D_{n} / B_{n}
$$

$R_{w}, R_{d}$ are fixed parameters representing reproductive success, namely the number of living mites, including the mother, which emerge from a worker and a drone brood cell, respectively; $k$ is the (fixed) daily mortality rate; and where $\mathrm{W}_{\mathrm{n}}$ (the number of worker cells available for entry by mites on day $n$ ), $D_{n}$ (the number of drone cells available for entry by mites on day $n$ ), $B_{n}$ (the mass in grams of adult bees in the colony on day $n$ ) are pre-determined functions of time which constitute the 'colony model'. 